\title{
Performance of Crambe Submitted to Aluminum Stress: An Important Oilseed Plant
}

\author{
Lucas B. de C. Rosmaninho' ${ }^{1}$ L. A. S. Dias ${ }^{1}$, Martha F. da Silva ${ }^{1}$, Aline de A. Vasconcelos ${ }^{2}$, \\ Wedisson O. Santos ${ }^{2}$, Carlos Eduardo A. Perez ${ }^{3}$, Leonardus Vergutz ${ }^{2} \&$ Lurian G. Cardoso $^{1}$ \\ ${ }^{1}$ Department of Plant Science, Universidade Federal de Viçosa, Viçosa, MG, Brazil \\ ${ }^{2}$ Department of Soil Science, Universidade Federal de Viçosa, Viçosa, MG, Brazil \\ ${ }^{3}$ Department of Plant Physiology, Universidade Federal de Viçosa, Viçosa, MG, Brazil \\ Correspondence: Lucas B. de C. Rosmaninho, Department of Plant Science, Universidade Federal de Viçosa, \\ Viçosa, MG, Brazil. Tel: 55-229-9794-8787. E-mail: lucasbcrosmaninho@hotmail.com
}

Received: September 17, 2018

Accepted: November 3, 2018

Online Published: January 15, 2019

doi:10.5539/jas.v11n2p454

URL: https://doi.org/10.5539/jas.v11n2p454

This study was financed in part by the Coordenação de Aperfeiçoamento de Pessoal de Nivel Superior-Brasil (CAPES)-Finance Code 001.

\begin{abstract}
Crambe is a potential oilseed plant, which has been suggested for cultivation as a cover crop in the Brazilian Savanna where acidic soils predominate. Understanding of its performance in those conditions is essential. Thus, the objective of this study was to characterize the morphological and physiological changes in crambe plants when subjected to $\mathrm{Al}$ exposure at different dose levels. Plants were allocated to a nutrient solution with $\mathrm{Al}$ treatments at concentrations of $0.0,0.1,0.2,0.3$ and $0.4 \mathrm{mmol} \mathrm{L}^{-1}$. The following parameters were determined: length of root (LR) and shoot (LS), dry mass of roots (RDM) and shoots (SDM), Al uptake in plant tissues, leaf area (LA), absolute growth rate (AGR), grain yield (GY), net $\mathrm{CO}_{2}$ assimilation rate $(A)$, stomatal conductance $\left(g_{s}\right)$, transpiration rate $(E)$ and chlorophyll $\alpha$ fluorescence. The experimental design was completely randomized, consisting of five treatments with four replications. Regression analyses of growth parameters and mean comparative tests of physiological traits were performed. Roots concentrated approximately 40 -fold more $\mathrm{Al}$ than shoots. There was a linear reduction in LS and LR with increasing doses of Al. For RDM, SDM, LA, AGR and GY, the reductions were similar and were better explained by quadratic models. Al damaged the photosynthetic apparatus of crambe plants, demonstrated by a significant reduction in the values of $\mathrm{Fv} / \mathrm{Fm}$ (estimation of photosynthetic efficiency), $A, g s$ and $E$, compared to the control. Al negatively affected growth parameters as well as the photosynthetic response of crambe plants, resulting in a substantial decrease in its grain yield.
\end{abstract}

Keywords: agroenergy, aluminum toxicity, Crambe abyssinica Hochst, nutrient solution, photosynthesis

\section{Introduction}

Crambe (Crambe abyssinica Hochst) is an oilseed plant, which has the potential for production of biodiesel, biodegradable plastics, dyes, lubricants, cosmetics, synthetic rubber and other products (Souza et al., 2009; Falasca et al., 2010; Pitol et al., 2010). Grain yield of crambe crops is approximately $1.500 \mathrm{~kg} \mathrm{ha}^{-1}$ with seeds having an oil content of approximately $36 \%$, rich in erucic acid (58\%). In addition, is a short cycle crop (about 100 days) that can be grown in the autumn/winter off-season (Pitol et al., 2010; Cardoso et al., 2012; Silveira et al., 2017).

Due to its rusticity, crambe has been shown to be highly adapted to weather and soil conditions in Brazil (Toebe et al., 2010). However, an important aspect to be considered for the establishment of this crop in tropical conditions is Al toxicity, the main abiotic limiting factor for plant production in Brazilian areas compounded by highly weathered soils (Kochian et al., 2015). Al is the most abundant metal in the earth's crust. However, its toxicity to plants is most pronounced in acidic soils which present a $\mathrm{pH}_{\text {water }}$ generally less than 5.5 , with $60 \%$ of these soils located in tropical and subtropicals regions, including Brazilian territory (Von Uexküll \& Mutert, 1995). 
The ionic $\mathrm{Al}$ form $\left(\mathrm{Al}^{3+}\right)$ inhibits mainly the growth and functional activities of roots, leading to water and nutritional deficiency in plants (Kochian et al., 2015). Al may also cause disturbance in cellular metabolism affecting the $\mathrm{CO}_{2}$ assimilation rate. The formation and function of chloroplasts can be altered by the presence of $\mathrm{Al}^{3+}$, affecting the thylakoid membranes and transport of electrons between photosystems (Akaya \& Takenaka, 2001; Peixoto et al., 2002).

Aluminum-plant relationships do not follow a pattern, since species and varieties differ widely in their performance in the presence of this element. Tolerant plants are those that continue to grow even in the presence of $\mathrm{Al}$, by use of exclusion or other mechanisms associated with detoxification or the trapping of absorbed $\mathrm{Al}$ (Kochian et al., 2015). On the other hand, sensitive plants are those that present morphophysiological changes, due to the absence of mechanisms that allow coexistence with the stressor (Taiz \& Zeiger, 2013). There is evidence that 2.4 to $5.0 \mathrm{mmol}_{\mathrm{c}} \mathrm{dm}^{-3}$ of $\mathrm{Al}^{3+}$ in soil is sufficient to decrease crop yields (Carvalho \& Raij, 1997). According to Krämer (2010), the critical level of Al toxicity in plant tissues is approximately $200 \mathrm{mg} \mathrm{kg}^{-1}$. Species accumulating more than $1000 \mathrm{mg} \mathrm{kg}^{-1}$ are considered to be hyperaccumulators of this element. Crambe plants growth well in soils with low active acidity may indicate that this species does not tolerate acidic soils which consequently present high $\mathrm{Al}^{3+}$ availability. Therefore, this finding suggests that crambe plants are sensitive to $\mathrm{Al}$ (Broch \& Roscoe, 2010). Given that it been suggested that crambe plants are cultivated as cover crop mainly in the Brazilian Savanna (Cerrado) where acidic soils predominate, knowledge of its performance in these conditions is essential. Thus, the objective of this study was to characterize the morphological and physiological effects in crambe plants subjected to $\mathrm{Al}$ exposure at different doses.

\section{Material and Methods}

\subsection{Experimental Procedures}

The trial was conducted in a greenhouse of the Department of Soil Science at the Federal University of Viçosa, Viçosa, MG, Brazil. Crambe seeds (cultivar FMS Brilhante), provided by the Fundação Mato Grosso do Sul, were germinated in cells containing commercial substrate.

When the first true leaf appeared, after $14 \mathrm{~d}$ from the date of sowing (DAS), the plants were transplanted to a hydroponic medium in trays under forced aeration. Plants were acclimated for $15 \mathrm{~d}$ in a complete nutrition solution, as described by Hoagland and Arnon (1950), with a $\mathrm{pH}$ of $\sim 6$ and $50 \%$ of salt concentration. After the acclimation period, plants were transferred to 5 - $\mathrm{L}$ pots, maintaining the aeration, using a nutrient solution ( $\mathrm{pH} \sim 4$ ) that was half strength (50\% salt concentration) of report by Hoagland and Arnon (1950), with the amount of phosphorus (P) adjusted to 1/10th of its original concentration. The $\mathrm{P}$ concentration and the $\mathrm{pH}$ of the solution were kept low to minimize the possible precipitation of insoluble forms of Al (Braccini et al., 1998).

The treatments consisted of five $\mathrm{Al}$ concentrations: 0, 0.1, 0.2, 0.3 and $0.4 \mathrm{mmol} \mathrm{L}^{-1}(\mathrm{pH} 4)$, supplied as aluminum chloride $\left(\mathrm{AlCl}_{3}\right)$, with $0 \mathrm{mmol} \mathrm{L}{ }^{-1} \mathrm{Al}$ representing the control treatment. The trial was carried out as a completely randomized design with four replications. An experimental unit was composed of a 5-L pot containing one plant. The nutrient solution exchange occurred when checked the depletion of $30 \%$, according to the electrical conductivity of the solution. The $\mathrm{pH}$ of the solution was adjusted daily with $\mathrm{NaOH}$ or $\mathrm{HCl}(0.5 \mathrm{~mol}$ $\left.\mathrm{L}^{-1}\right)$.

\subsection{Growth Parameters}

\subsubsection{Length of Root and Shoot (LR and LS)}

The length of the primary root was determined by measuring the distance between the apex of the root and the base of the plant. The shoot length was measured from the stem apex. Both measurements were performed with a measuring tape.

\subsubsection{Root and Shoot Dry Matter (RDM and SDM)}

The plants were sectioned into roots and shoots. Shoot and root samples were dried in a forced air circulation oven at $60 \pm 5^{\circ} \mathrm{C}$ until constant weight was achieved and were subsequently weighed.

\subsubsection{Aluminum Uptake in the Plant Tissues}

After nitroperchloric digestion (Johnson \& Ulrich, 1959) of the plant tissues (roots and shoots), Al content was determined by optical emission spectrophotometry with induction coupled plasma (Perkin Elmer, Optima model DV 3300). 


\subsubsection{Leaf Area (LA)}

Crambe leaves are wider at the base and tapered at the ends. Therefore, for the measurement of leaf area, four leaves from each treatment were divided into two sections: basal central part (rectangular shape) and apical part (triangular shape). The area of the rectangle that enclosed the limbus was determined as the product of the leaf width and length. The length was obtained with graduated rule, oriented towards the midrib, and the width by rule in the central region, towards the midrib. The area of the triangle was determined by the width of the central region, measured across the rib, and the height by the length of half the limbus to the apex.

\subsubsection{Absolute Growth rate (AGR)}

Four plants for each treatment were weighed using a precision digital scale at 30 DAS to obtain the mass before exposure to Al. After a 70-day period of exposure to Al, the increase in dry matter was measured according to the methodology proposed by Reis and Muller (1979), defined by the following equation:

$$
A G R=\left(w_{2}-w_{1}\right) /\left(t_{2}-t_{1}\right)
$$

where, $w_{1}$ and $w_{2}$ are the changes in mass of the dry matter in two consecutive samples taken at the times $t_{1}(30$ DAS) and $t_{2}$ (90 DAS).

\subsection{Grain Yield (GY)}

The grain yield (g) per plant was also determined.

\subsection{Physiological Parameters}

\subsubsection{Determination of Gas Exchange and Chlorophyll Fluorescence}

During the period of grain maturation, gas exchange and chlorophyll fluorescence were determined with a portable IRGA (LI 6400XT, Li-Cor Inc., Lincoln, NE) equipped with fluorescence camera (LI-6400). The net $\mathrm{CO}_{2}$ assimilation rate $(A)$, stomatal conductance $\left(g_{s}\right)$ and transpiration rate $(E)$ were measured on fifth fully expanded leaf plants with saturating light of $1200 \mu \mathrm{mol} \mathrm{m} \mathrm{s}^{-1}, 400 \mu \mathrm{mol} \mathrm{mol}^{-1} \mathrm{CO}_{2}$ and a temperature of $25^{\circ} \mathrm{C}$. The readings were performed between 8:00 a.m. and 12:00 p.m.

The leaves previously adapted to the dark (from 5:00 to 6:00 a.m.) were illuminated with red light of low intensity $\left(0.03 \mu \mathrm{mol} \mathrm{m}^{2} \mathrm{~s}^{-1}\right)$ to obtain the minimum fluorescence $\left(F_{0}\right)$. Saturating white light pulses of $8000 \mu \mathrm{mol}$ $\mathrm{m}^{2} \mathrm{~s}^{-1}$ were then applied for $0.8 \mathrm{~s}$ to ensure maximum fluorescence emission $\left(F_{m}\right)$. With these parameters, the quantum yield of photosystem II was calculated (Maxwell \& Johnson, 2000):

$$
F_{v} / F_{m}=\left(F_{m}-F_{0} / F_{m}\right)
$$

\subsection{Statistical Procedure}

Data concerning for the parameters evaluated were submitted to statistical analyses using Minitab software. Regression analyses were performed for the agronomic traits being the interpretation based on biological significance, angular coefficients (tested by Student's t-test) and values of the coefficients of determination $\left(\mathrm{R}^{2}\right)$ (Dias \& Barros, 2009). Mean comparative Dunnett's test was performed on physiological traits. For all statistical analyses a $5 \%$ level of significance was used.

\section{Results}

\subsection{Aluminum Uptake by Plants}

Aluminum concentration in both roots and shoots of crambe plants increased linearly with increasing doses (Figure 1). Roots concentrated about 40 -fold more $\mathrm{Al}$ than shoots. In comparison to the control treatment, there was a 3.5-fold increase in the $\mathrm{Al}$ concentration in roots and a 3-fold increase in shoots at the highest dose $(0.4$ $\left.\mathrm{mmol} \mathrm{L}{ }^{-1}\right)$. The findings show that roots of crambe plants accumulate more $\mathrm{Al}$ than shoots. Contrasting trends were observed in $\mathrm{Al}$ uptake by plant roots and shoots with increasing doses (Figure 2). Indeed, at an estimated Al dose of $0.23 \mathrm{mmol} \mathrm{L}^{-1}$ there was higher accumulation of this element in root tissues, which followed a quadratic model response. In contrast, the accumulation of $\mathrm{Al}$ in shoots linearly decreased by half with increasing $\mathrm{Al}$ doses up to $0.4 \mathrm{mmol} \mathrm{L}^{-1}$. 

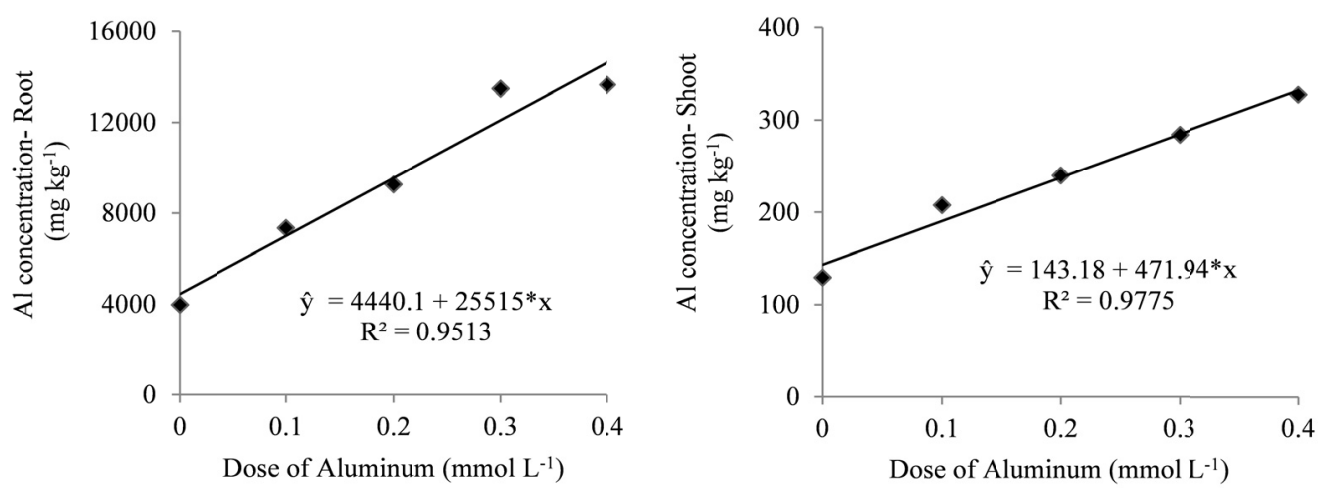

Figure 1. Aluminum concentration in roots and shoots of crambe plants subjected to increasing doses of Al.

Average data of four replications. ${ }^{*}$ Significant at $5 \%$ probability by Student's t-test $(\mathrm{p} \leq 0.05)$
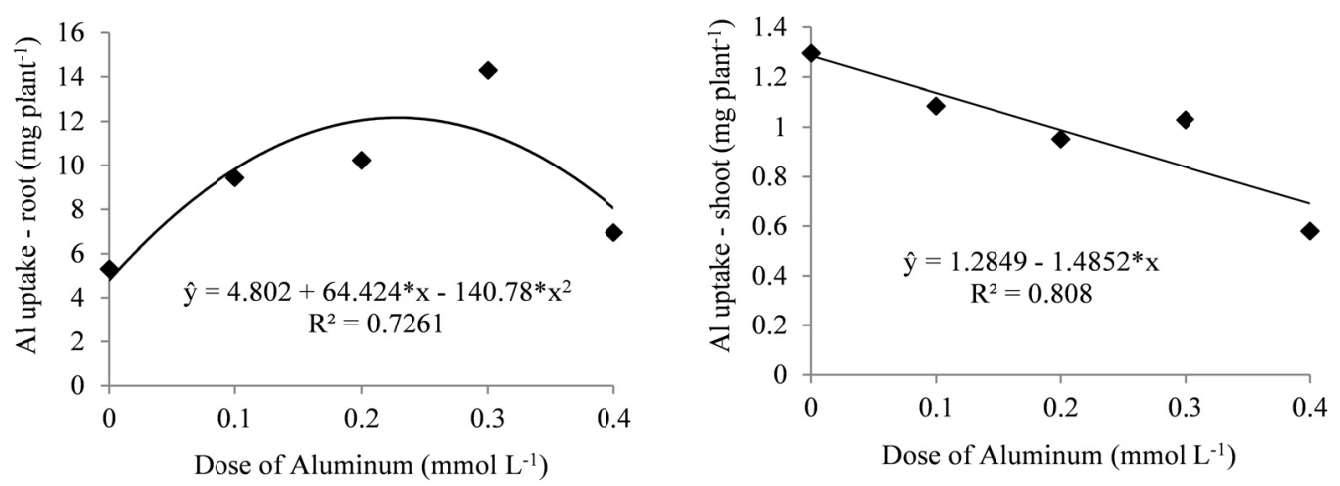

Figure 2. Aluminum uptake by root and shoot of crambe plants subjected to increasing doses of Al. Average data of four replications. * Significant at 5\% probability by Student's t-test $(\mathrm{p} \leq 0.05)$

\subsection{Length and Dry Mass of Roots and Shoots, Leaf Area and Absolute Growth Rate}

The harmful effects of Al might be demonstrated by significant decreases compared to the control treatment (no $\mathrm{Al}$ application) in length of root (LR) and shoot (LS), root dry mass (RDM) and shoot dry mass (SDM), leaf area (LA) and absolute growth rate (AGR) (Figure 3). Thus, there was a linear reduction in LS and LR with increasing doses of Al. At a dose of $0.4 \mathrm{mmol} \mathrm{L}^{-1}$, LS and LR were $33 \%$ and $35 \%$ lower than the control treatment, respectively. For RDM, SDM, LA and AGR, the reductions due to increasing Al doses were similar; however, quadratic models explained it better (Figure 3).

Changes in accumulation of dry mass in crambe plants subjected to different concentrations of $\mathrm{Al}$ involved significant decreases in absolute growth rate (AGR) of 47, 60, 60 and $87 \%$ at doses of $0.1,0.2,0.3$ and $0.4 \mathrm{mmol}$ $\mathrm{L}^{-1}$, respectively, compared with control treatment (Figure 3). Increasing doses of Al negatively affected root $(\mathrm{RDM})$ and shoot dry matter (SDM) accumulation (Figure 3). Interestingly, there was a reduction of $4 \%$ in RDM for the plants submitted to $\mathrm{Al}$ at $0.1 \mathrm{mmol} \mathrm{L}^{-1}$ compared with the control treatment, while there was a decrease in SDM of $48 \%$. At the highest dose of $\mathrm{Al}\left(0.4 \mathrm{mmol} \mathrm{L}^{-1}\right)$, there was a reduction of $62 \%$ and $83 \%$ of $\mathrm{RDM}$ and SDM, respectively, compared with the control treatment (Figure 3). 

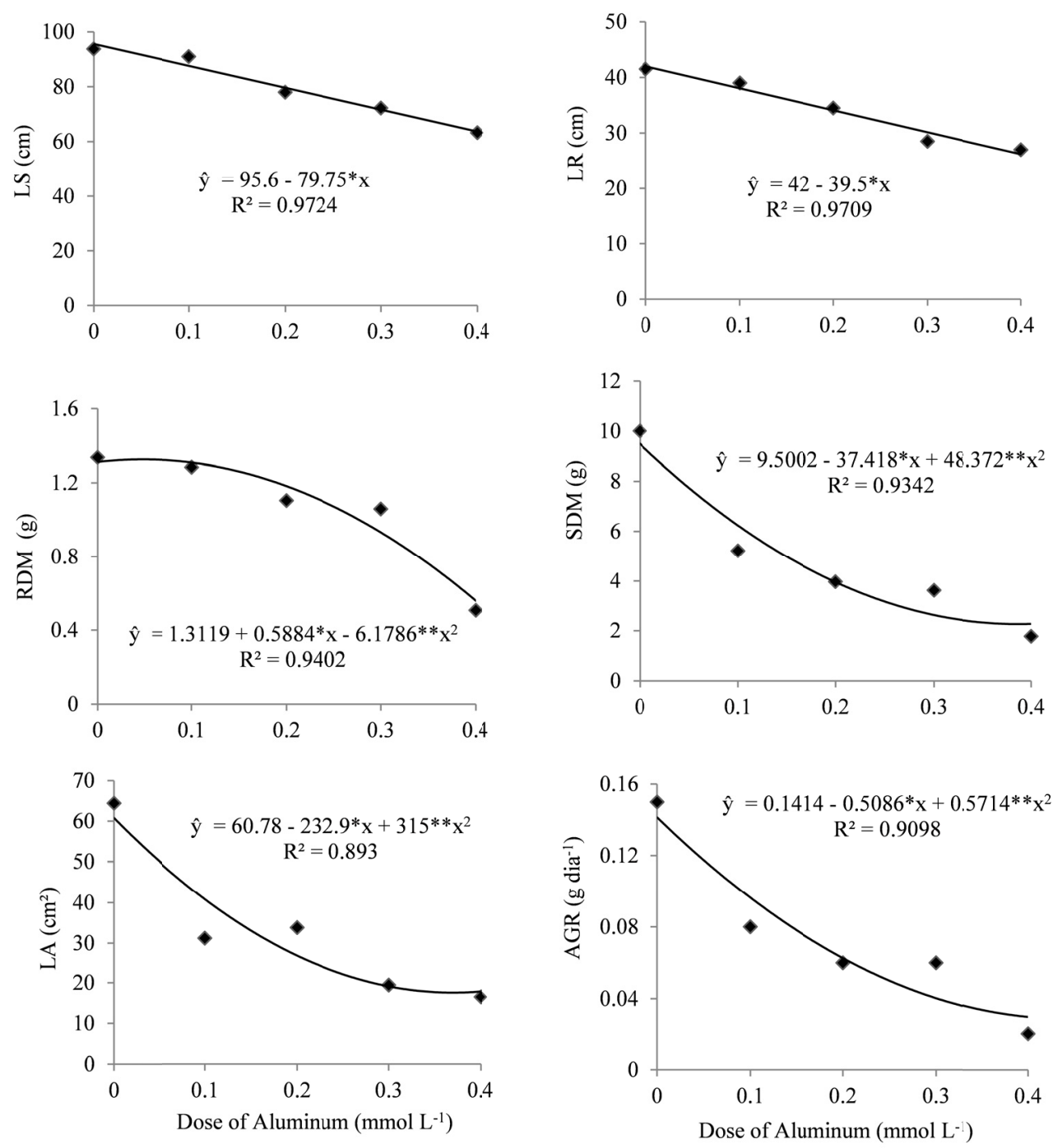

Figure 3. Length of shoot (LS) and root (LR), root dry mass (RDM) and shoot dry mass (SDM), leaf area (LA) and absolute growth rate (AGR) in crambe plants subjected to increasing doses of Al. Average data of four replications. * Significant at $5 \%$ probability by Student's t-test

Changes were also observed in the color and thickness of the roots in plants submitted to Al stress. The damaged roots became brownish and thicker. At the highest $\mathrm{Al}$ dose, the presence of finer and branched roots was reduced in comparison with the control treatment (Figure 4). 


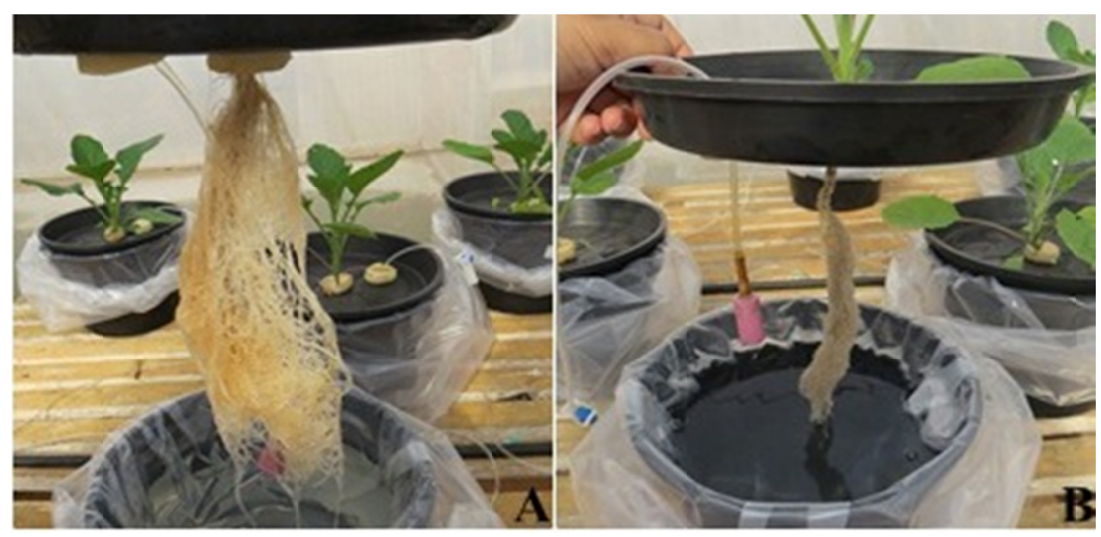

Figure 4. Details of root morphology in crambe plants. Note that the root system with the control treatment (no

Al-application) showed longer and bulky roots with normal coloration (A), different to when the plants were submitted to the highest dose of $\mathrm{Al}\left(0.4 \mathrm{mmol} \mathrm{L}^{-1}\right)$, showing smaller and thicker roots with a brownish color (B)

A clear decrease (75\%) was also observed in leaf area (LA) at the highest dose of $\mathrm{Al}$ compared to the control treatment. In addition, Al-toxicity promoted chlorosis which evolved into necrosis in old leaves of crambe (Figure 5).

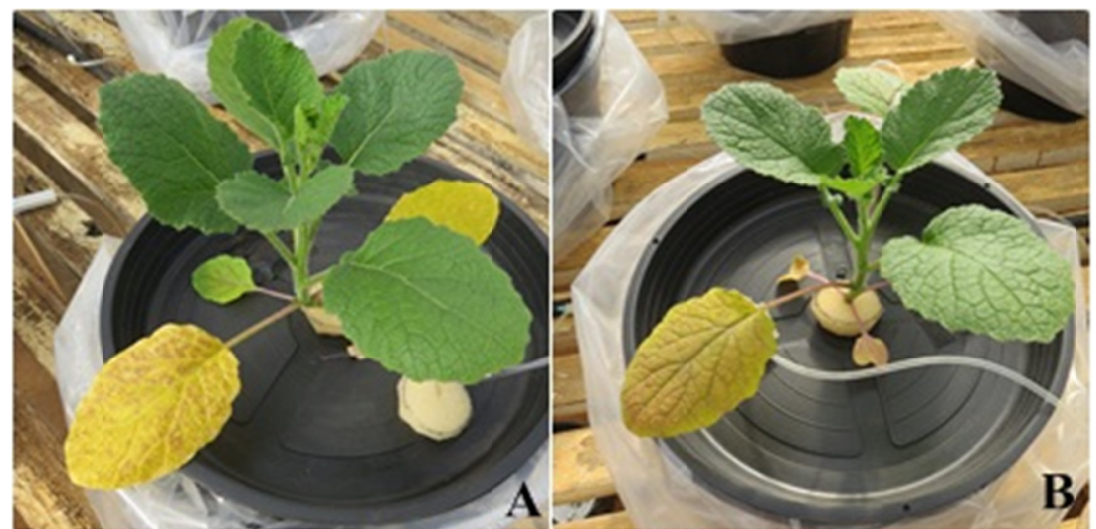

Figure 5. Leaves of crambe plants submitted to Al stress at a dose of $0.4 \mathrm{mmol} \mathrm{L}^{-1}$. A, B: Detail of the occurrence of chlorosis

\subsection{Gas Exchange and Chlorophyll Fluorescence}

Increasing the exposure of crambe plants to $\mathrm{Al}$ caused damage in the photosynthetic apparatus, demonstrated by a significant reduction in the values of $F_{v} / F_{m}$, net $\mathrm{CO}_{2}$ assimilation rate $(A)$, stomatal conductance $\left(g_{s}\right)$ and the transpiration rate $(E)$ compared to the control treatment (Figure 6). For example, at $\mathrm{Al}$ doses of 0.1, 0.2, 0.3 and $0.4 \mathrm{mmol} \mathrm{L}^{-1}$ there were reductions in $A$ of 34, 48, 82 and $93 \%$, respectively (Figure 6). 

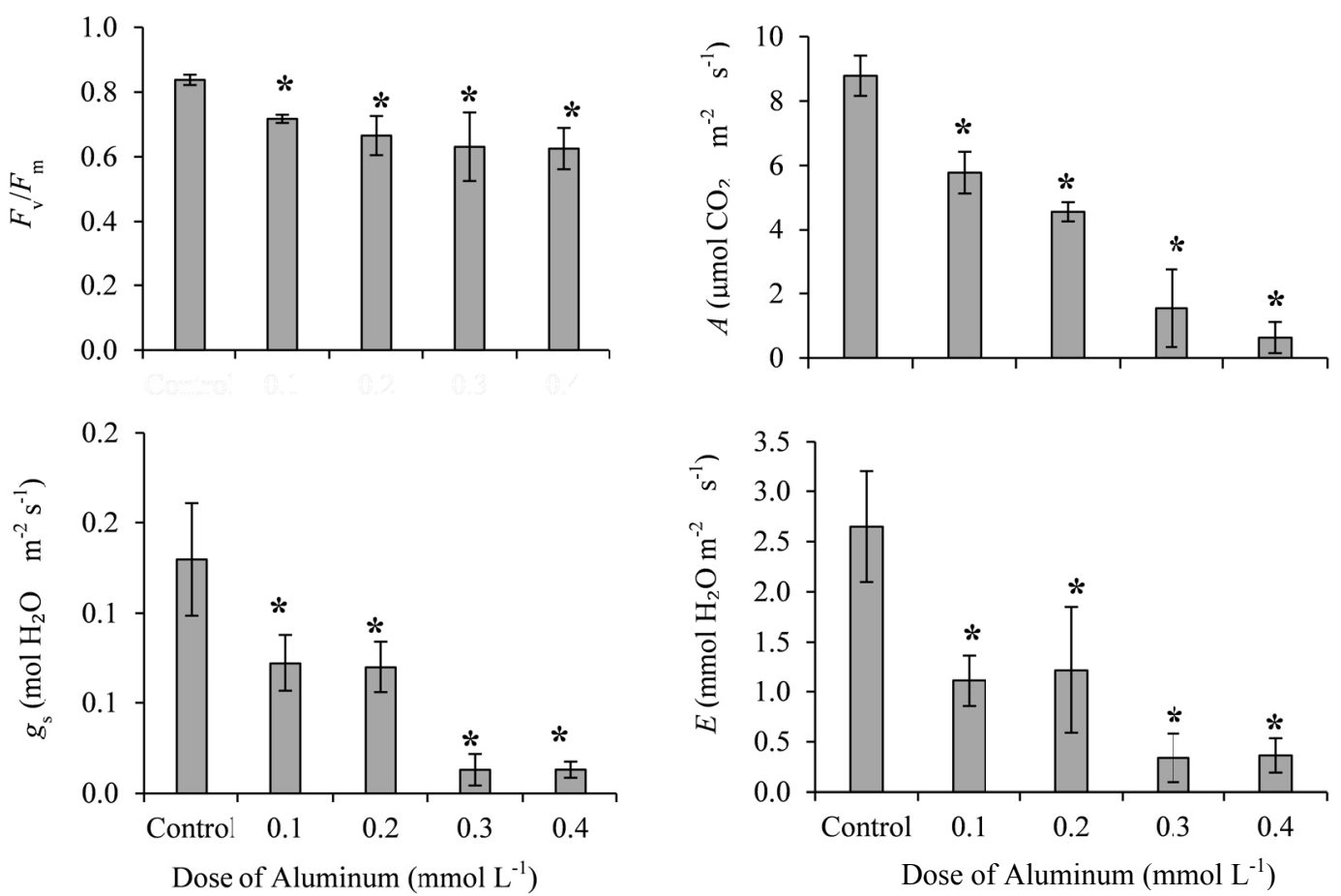

Figure 6. Quantum efficiency of photosystem II $\left(F_{\downarrow} F_{m}\right)$, net $\mathrm{CO}_{2}$ assimilation rate $(A)$, stomatal conductance $\left(g_{s}\right)$ and transpiration rate $(E)$ in crambe plants subjected to increasing doses of aluminum. Average values followed

by asterisk $(*)$ were significantly different $(\mathrm{P} \leq 0.05)$ by Dunnett's test. The lines on the bars represent the standard deviation, based on four replications

\subsection{Grain Yield}

There was a reduction in grain yield with increasing dose of $\mathrm{Al}$ (Figure 7). In fact, the grain yield declined by 67, 72,87 and $93 \%$ compared with control treatment at $\mathrm{Al}$ doses of $0.1,0.2,0.3$, and $0.4 \mathrm{mmol} \mathrm{L}^{-1}$, respectively.

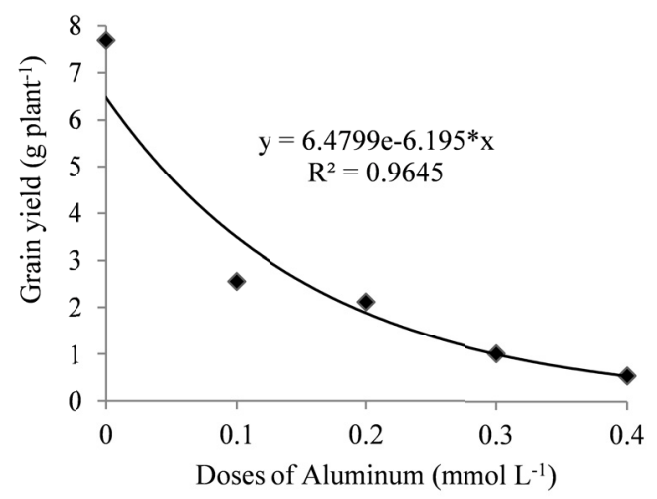

Figure 7. Grain yield in crambe plants subjected to different doses of Al. Average data from four replications.

*Significant at $5 \%$ probability by Student's t-test

\section{Discussion}

\subsection{Aluminum Affecting Plant Growth}

Crambe was shown as a clear sensibility plant to Al stress. In addition, our findings also indicate that the root system of crambe is where most $\mathrm{Al}$ is accumulated being part of the plant most affected by $\mathrm{Al}$ toxicity. The lower concentrations of $\mathrm{Al}$ in the shoots and leaves may be a result of the epidermis acting as a barrier which reduces transport of this element (Vitorello et al., 2005). 
The sensitivity of crambe to $\mathrm{Al}$ toxicity in terms of plant growth and grain yield, reported here, is supported by results of other studies (Broch \& Roscoe, 2010; Colodetti et al., 2015). Silva et al. (2017) found that when the base saturation of the soil was $70 \%$, crambe plants achieved higher grain yield. However, at this saturation, the $\mathrm{pH}$ of the soil was around 5.5, the $\mathrm{pH}$ at which $\mathrm{Al}^{3+}$ is fully hydrolyzed. Therefore, we presume that this finding also reinforces the high sensitivity of crambe plants to $\mathrm{Al}^{3+}$. The morphological and physiological changes in crambe plants exposed to $\mathrm{Al}$, presented in this study, will facilitate understanding of the sensitivity of the crop, which is of great importance in understanding the relationship between plant and environment, and for plant genetic breeding.

A primary symptom of Al toxicity demonstrated in this study was inhibition of root growth, resulting in a reduced and damaged root system that limited the absorption of water and nutrients by plants leading to morphological and physiological disorders which affected the whole plant. Indeed, inhibition of root growth is an important symptom of sensitivity, since Al disrupts cytoskeletal dynamics, interacting negatively with microtubules and actin filaments, preventing elongation of the outer cells to the rizhoderme (Sivaguru et al., 2003; Sun et al., 2010). Al toxicity also blocks the mechanism of cell division, causing the roots to become stunted and brittle and for changes in the color of this tissue to occur (Panda et al., 2009). Symptoms of Al toxicity are also manifested in the shoots as a consequence of damage to the root system that culminates with the decrease in plants growth. Aluminum toxicity may also result in apoptotic injuries and cell wall and the plasma membrane interactions (Dipierro et al., 2005), affecting the plant growth. The stagnation of crambe plant growth subjected to high concentrations of $\mathrm{Al}^{3+}$, as observed in this study, was also reported by Colodetti et al. (2015). Al uptake by plants affected cells and organelles at morphological and cytogenetic levels, damaging the development and establishment of crops (Macedo et al., 2008; Crestani et al., 2009).

Plant biomass was also impaired in this study. Costa et al. (2014), working with crambe plants exposed to Al, also observed a more pronounced decrease in SDM than in RDM. The decrease in biomass production can be related to a reduction in root growth and compromised nutrient uptake in the presence of Al (Tabaldi et al., 2007).

AGR represents the variation of growth or increase in dry matter between two successive samplings, indicating the speed of growth of the plant (Benincasa, 2004). The reduction of AGR can be attributed to the reduction in leaf area and decrease in the mass of the plant (Figure 3). In the present research, exposure to $\mathrm{Al}$ resulted in the lowest growth rate. Thus, a longer period of exposure to $\mathrm{Al}$ generated a lower growth rate in crambe, confirming the increase in the plant's sensitivity to this element.

\subsection{Aluminum Stress on Physiological Parameters}

To introduce this part of the discussion, we use the standard of dissipation of solar energy by chlorophyll $\alpha$ fluorescence as a method for estimating the degree of disturbance of the photosynthetic process (Baker, 2008). The $F_{v} / F_{m}$ relationship is an indicator of stress in plants, which is related to maximum efficiency estimator of photochemical activity of photosystem II (PSII), when all of its reaction centers are open (Baker, 2008). In non-stressed plants, the value of $F_{v} / F_{m}$ was reported to be around 0.8 , with values below this interpreted as indicative of plants under stress (Maxwell and Johnson, 2000). The response shown in $F_{v} / F_{m}$ is due to changes in the ability of oxidation reaction centers in PSII ( $>$ value of $F_{0}$ ), limiting the ability of excitation energy transfer from the antenna to the reaction center (Baker and Rosenqvst, 2004). Similarly, another associated problem is the reduction in the maximum intensity of fluorescence $\left(<\right.$ value of $\left.F_{m}\right)$ when the pool of quinones is reduced, causing reaction centers not to reach maximum capacity of photochemical reactions. Thus, Al dramatically disrupts the photochemical capacity of crambe plants, which is associated with changes in functionality and structure of the thylakoid membranes of chloroplasts, causing changes in the fluorescence parameters (Ribeiro et al., 2004). Ali et al. (2008) showed that $\mathrm{Al}$ induced a decrease in the chlorophyll content and photosynthetic rate.

Decrease in the $\mathrm{CO}_{2}$ stream toward the sites of carboxylation in the chloroplast was related to lower stomatal opening $\left(<g_{s}\right)$, demonstrating strong stomatal limitations that were modulated by the presence of $\mathrm{Al}$ in the growing medium. Stomatal closure leads to difficulties in respiration, since it is through the stomata that most evapotranspiration of plants takes place. In this way, the photosynthetic and transpiration rate are directly associated with the occurrence of stomatal opening, therefore, fall in its parameters with the reduction of $g_{s}$. Peixoto et al. (2002) and Akaya and Takenaka (2001) also noted that the fall of $g_{s}$ contributed to the fall of $A$ in plants subjected to stress caused by Al. Chen et al. (2002) reported that stomatal closure was an important ecophysiological response of plants to stressful situations. Several studies have concluded that Al influences the reduction of photosynthetic pigments, as well as the uptake and transport of nutrients such as $\mathrm{Mg}$, which are present in the chlorophyll molecule (Milivojevic \& Stojanovic, 2003). The presence of Al may compromise the 
function of photosystem II (Ali et al., 2008), cause disturbances in the structure of chloroplasts (Saleem et al., 2011) and damage the thylakoid (Pereira et al., 2000), all of which limit photosynthetic activity. According to Vitorello et al. (2005), and Rangel et al. (2009), the reduction of gas exchange rates is a common feature of Al-sensitive plants when in the presence of this element. The damage to the photosynthetic apparatus of plants (Figure 6) reported in this study was associated with the reduction in $\mathrm{CO}_{2}$ assimilation, stomatal conductance and transpiration and damaged the grain yield (Figure 7).

According to Kochian et al. (2015), Al-tolerant species are those with mechanisms that prevent the entry of this element into root cells or that have the ability to detoxify $\mathrm{Al}$ that is absorbed. When the exclusion mechanisms are inefficient and $\mathrm{Al}$ can reach the cells, it can still be detoxified by complexation with organic compounds (Ma \& Miyasaka, 1998; Balaji et al., 2003) or by chelating agents, and can be transported to the vacuoles and stored without causing toxicity (Kochian et al., 2004). In these species, disorders in growth, physiology or morphology do not occur. Already the susceptible species are those that have its metabolism (including decrease in photosynthetic rate) and their morphological parameters damaged.

\section{Conclusion}

Aluminum negatively affected growth parameters (root and shoot length, root and shoot dry mass, absolute growth rate and leaf area), as well as the photosynthetic response of crambe plants (caused by stomatal limitation and damage to the photosynthetic machinery), which resulted in a substantial decrease in grain yield of the crop. Our article not only confirmed the sensitivity of crambe to Al toxicity, but also studied in detail the major disorders and the negative effects of $\mathrm{Al}$ on plants. That is precisely what our article proposes as a novelty.

\section{References}

Akaya, M., \& Takenaka, C. (2001). Effects of aluminum stress on photosynthesis of Quercus glauca Thrumb. Plant and Soil, 237, 137-146. https://doi.org/10.1023/A:1013369201003

Ali, B., Hasan, S. A., Hayat, S., Hayat, Q., Yadav, S., Fariduddin, Q., \& Ahmad, A. (2008). A role for brassinosteroids in the amelioration of aluminium stress through antioxidant system in mung bean (Vigna radiata L. Wilczek). Environmental and Experimental Botany, 62, 153-159. https://doi.org/10.1016/ j.envexpbot.2007.07.014

Baker, N. R. (2008). Chlorophyll fluorescence: A probe of photosynthesis in vivo. Annual Review of Plant Biology, 59, 89-113. https://doi.org/10.1146/annurev.arplant.59.032607.092759

Baker, N. R., \& Rosenqvst, E. (2004). Applications of chlorophyll fluorescence can improve crop production strategies: an examination of future possibilities. Journal of Experimental Botany, 55, 1607-1621. https://doi.org/10.1093/jxb/erh196

Balaji, M., Reddy, B. K., Jogeswar, G., Reddy, L. A., \& Kavi Kishor, P. B. (2003). Alleviating effect of citrate on aluminum toxicity of rice (Oryza sativa L.) seedlings. Current Science, 85, 383-386.

Benincasa, M. M. P. (2004). Análise de crescimento de plantas (noções básicas) (p. 41). Funep, Jaboticabal.

Braccini, M. C. L., Martinez, H. E. P., Pereira, P. R. G., Sampaio, N. F., \& Pereira, A. A. (1998). Tolerância de genótipos de cafeeiro ao alumínio em solução nutritiva. II. Teores de $\mathrm{P}, \mathrm{Ca}$ e $\mathrm{Al}$ e eficiência ao $\mathrm{P}$ e $\mathrm{Ca}$. Revista Brasileira de Ciência do Solo, 22, 443-450. https://doi.org/10.1590/S0100-06831998000300010

Broch, D. L., \& Roscoe, R. (2010). Fertilidade do solo, adubação e nutrição do crambe. In M. S. Fundação (Ed.), Tecnologia e produção: Crambe 2010 (pp. 22-36). Fundação, MS, Maracajú.

Cardoso, R. B., Da Silva Binotti, F. F., \& Cardoso, E. D. (2012). Potencial fisiológico de sementes de crambe em função de embalagens e armazenamento. Pesquisa Agropecuária Tropical, 42, 272-278. https://doi.org/ $10.1590 /$ S1983-40632012000300006

Carvalho, M. C. S., \& Raij, B. van. (1997). Calcium sulphate, phosphogypsum and calcium carbonate in the amelioration of acid subsoils for root growth. Plant Soil, 192, 37-48. https://doi.org/10.1023/ A:1004285113189

Chen, H., Qualls, R. G., \& Miller, G. C. (2002). Adaptative responses of Lepidium latifolium to soil flooding: biomass allocation, adventitious rooting, aerenchyma formation and ethylene production. Environmental and Experimental Botany, 48, 119-128. https://doi.org/10.1016/S0098-8472(02)00018-7

Colodetti, T. V., Rodrigues W. N., Deleon M., \& Tomaz, M. A. (2015). Aluminum stress in Crambe abyssinica Hochst. Idesia, 33, 2. https://doi.org/10.4067/S0718-34292015000200004 
Costa, D. P., Costa-Júnior, D. S., Hora, V. M., Abreu, C. B., \& Azevedo Neto, A. D. (2014). O estresse por alumínio afeta o crescimento e acúmulo de NPK em plantas de crambe? Enciclopédia Biosfera, 10, 1359-1366.

Crestani, M., Carvalho, F. I. F., Oliveira, A. C., Silva, J. A. G., Souza, V. Q., Parachu, E. A. M., ... Luche, H. S. (2009). Estresse por alumínio em genótipos de aveia preta em condição hidropônica. Bragantia, 68, 639-649. https://doi.org/10.1590/S0006-87052009000300010

Dias, L. A. S., \& Barros, W. S. (2009). Biometria experimental (p. 408). Suprema, Viçosa.

Dipierro, N., Mondelli, D., Paciolla, C., Brunetti, G., \& Dipierro, S. (2005). Changes in the ascorbate system in the response of pumpinkin (Cucurbita pepo L.) roots to aluminum stress. Journal of Plant Physiology, 162, 529-536. https://doi.org/10.1016/j.jplph.2004.06.008

Falasca, S. L., Lamas, M. C., Carballo, S. M., \& Anschau, A. (2010). Crambe abyssinica: An almost unknown crop with a promissory future to produce biodiesel in Argentina. International Journal of Hydrogen Energy, 35, 5808-5812. https://doi.org/10.1016/j.ijhydene.2010.02.095

Hoagland, D. R., \& Arnon, D. I. (1950). The water culture method for growing plants without soil. California Agricultural Experiment Station Publications, 347, 1-39.

Johnson, C. M., \& Ulrich, A. (1959). Analytical methods for use in plant analysis (pp. 32-33). University of California, Los Angeles.

Kochian, L. V., Hoekenga, O. A., \& Pineros, M. A. (2004). How do crop plants tolerate acid soils? Mechanisms of aluminum tolerance and phosphorus efficiency. Annual Review of Plant Biology, 55, 459-493. https://doi.org/10.1146/annurev.arplant.55.031903.141655

Kochian, L. V., Piñeros, M. A., Liu, J., \& Magalhaes, J. V. (2015). Plant adaptation to acid soils: the molecular basis for crop aluminum resistance. Annual Review of Plant Biology, 66, 571-598. https://oi.org/10.1146/ annurev-arplant-043014-114822

Krämer, U. (2010). Metal hyperaccumulation in plants. Annual Review of Plant Biology, 61, $517-534$. https://doi.org/10.1146/annurev-arplant-042809-112156

Ma, Z., \& Miyasaka, S. C. (1998). Oxalate exudation by taro in response to Al. Plant Physiology, 118, 861-865. https://doi.org/10.1104/pp.118.3.861

Macedo, C. M. P., Lopes, J. C., Amaral, J. A. T., \& Fonseca, A. F. A. (2008). Germinação e vigor de sementes de café submetidas ao estresse com alumínio. Scientia Agraria, 9, 235-239. https://doi.org/10.5380/rsa.v9i2. 11010

Maxwell, K., \& Johnson, G. N. (2000). Chlorophyll fluorescence a practical guide. Journal of Experimental Botany, 51, 659-668. https://doi.org/10.1093/jexbot/51.345.659

Milivojevic, D. B., \& Stojanovic, D. D. (2003). Role of calcium in aluminum toxicity on content of pigments and pigment-protein complexes of soybean. Journal of Plant Nutrition, 26, 341-350. https://doi.org/10.10 81/PLN-120017140

Panda, S. K., Baluška, F., \& Matsumoto, H. (2009). Aluminum stress signaling in plants. Plant Signaling \& Behavior, 4, 592-597. https://doi.org/10.4161/psb.4.7.8903

Peixoto, P. H. P., Da Matta, F. M., \& Cambraia, J. (2002). Responses of the photosynthetic apparatus to aluminum stress in two sorghum cultivars. Journal of Plant Nutrition, 25, 821-832. https://doi.org/10.10 81/PLN-120002962

Pereira, W. E., Siqueira, D. L., Martinez, C. A., \& Puiatti, M. (2000). Gas exchange and chlorophyll fluorescence in four citrus rootstocks under aluminium stress. J. Plant Physiology, 157, 513-520. https://doi.org/10.1016/ S0176-1617(00)80106-6

Pitol, C., Broch, D. L., \& Roscoe, R. (2010). Tecnologia e produção: Crambe (p. 60). Fundação MS, Maracaju.

Rangel, A. F., Rao, I. M., \& Horst, W. J. (2009). Intracellular distributing and biding state of aluminum in root apices of two common bean (Phaseolus vulgaris) genotypes in relation to Al toxicity. Physiology Plantarum, 135, 162-173. https://doi.org/10.1111/j.1399-3054.2008.01183.x

Reis, G. G., \& Muller, M. W. (1979). Análise de crecimento de plantas mensuração do crescimento (p. 39). Cpatu, Belém. 
Ribeiro, R. V., Machado, E. C., \& Oliveira, R. F. (2004). Growth and leaf temperature effects on photosynthesis of sweet orange plants infected with Xylella fastidiosa. Plant Pathology, 53, 334-340. https://doi.org/ 10.1111/j.0032-0862.2004.01012.x

Saleem, A., Ashraf, M., \& Akram, N. A. (2011). Salt $(\mathrm{NaCl})$ induced modulation in some key physio-biochemical attributes in okra (Abelmoschus esculentus L.). Journal of Agronomy and Crop Science, 197, 202-213. https://doi.org/10.1111/j.1439-037X.2010.00453.x

Silva, T. R. B., Carraro, T. V., Frigo, P., Barbosa, N. A., Tiburcio, M. G. G., Secco, D., \& Alves, C Z. (2017). Crambe development under lime application in sandy soil. Acta Iguazu, 6, 59-63.

Silveira, E. V., Vilela, L. S., De Souza Castro, C. F., Lião, L. M., Neto, F. F. G., \& De Oliveira, P. S. M. (2017). Chromatographic characterization of the crambe (Crambe abyssinica Hochst) oil and modeling of some parameters for its conversion in biodiesel. Industrial Crops and Products, 97, 545-551. https://doi.org/10.10 16/j.indcrop.2016.12.033

Sivaguru, M., Pike, S., Gassmann, W., \& Baskin, T. I. (2003). Aluminum rapidly depolymerizes cortical microtubules and depolarizes the plasma membrane: Evidence that these responses are mediated by a glutamate receptor. Plant Cell Physiology, 44, 667-75. https://doi.org/10.1093/pcp/pcg094

Souza, A. D. V., Fávaro, S. P., Ítavo, L. C., \& Roscoe, R. (2009). Caracterização química de sementes e tortas de pinhão manso, nabo-forrageiro e crambe. Pesquisa Agropecuária Brasileira, 44, 1328-1335. https://doi.org/ $10.1590 / \mathrm{S} 0100-204 \mathrm{X} 2009001000017$

Sun, P., Tian, Q. Y., Chen, J., \& Zhang, W. H. (2010). Aluminium-induced inhibition of root elongation in Arabidopsis is mediated by ethylene and auxin. Journal of Experimental Botany, 61, 347-356. https://doi.org/10.1093/jxb/erp306

Tabaldi, L. A., Nicoloso, F. T., Castro, G. Y., Carneglutti, D., Gonçalves, J. F., Rauber, R., ... Bisognin, D. A. (2007). Physiological and oxidative stress responses of four potato clones to aluminum in nutrient solution. Braz. J. Plant Physiology, 19, 211-222.

Taiz, L., \& Zeiger, E. (2013). Fisiologia vegetal (p. 719). ArtMed, Porto Alegre.

Toebe, M., Brum, B., \& Lopes, S.J. (2010). Estimativa da área foliar de Crambe abyssinica por discos foliares e por fotos digitais. Ciência Rural, 40, 475-478. https://doi.org/10.1590/S0103-84782010000200035

Vitorello, V. A., Capaldi, F. R., \& Stefanuto, V. A. (2005). Recent advances in aluminum toxicity and resistance in higher plants. Braz. J. Plant Physiology, 17, 129-143. https://doi.org/10.1590/S1677-04202005000 100011

Von Uexküll, H. R., \& Mutert, E. (1995). Global extend, development and economic-Impact of acid soils. Plant and Soil, 171, 5-19. https://doi.org/10.1007/BF00009558

\section{Copyrights}

Copyright for this article is retained by the author(s), with first publication rights granted to the journal.

This is an open-access article distributed under the terms and conditions of the Creative Commons Attribution license (http://creativecommons.org/licenses/by/4.0/). 